\title{
KRITIKAN PERKAWINAN BEDA AGAMA DI INDONESIA DALAM PERSPEKTIF ISLAM
}

\author{
Oleh: \\ Andrie Irawan \\ Universitas Cokroaminoto Yogyakarta
}

\begin{abstract}
Abstrak
Perkawinan beda Agama di lihat dari sisi anak pastinya akan muncul suatu kebingungan dalam menentukan aqidah anak di masa depan, hal ini mungkin terjadi ketika dia perbedaan Agama orang tuanya, padahal ada kewajiban bagi setiap orang tua untuk memberikan pelajaran dan pendidikan Agama sedini mungkin kepada anak terutama dalam islam sendiri dan dilain hal untuk mendapatkan pendidikan agama adalah hak anak. Hal yang paling mungkin timbul adalah kebingungan si anak dalam menentukan pilihan agamanya walaupun ada alasan setelah dewasa dia akan memilih sendiri, tapi bagaimana selama dia belum dianggap dewasa, apakah dapat mencampuradukkan dua agama berbeda menjadi hal yang wajar dan tidak menjadi masalah bagi setiap agama yang bersangkutan.

Di sisi lain juga ada kemaslahatan bagi setiap umat muslim sendiri dalam menjaga kemurnian dari ajaran agama islam yang akan di jalannkan dalam kehidupan pribadi dan keluarganya kelak, memang banyak bukti bahwa perkawinan beda agama langgeng dan tidak masalah dengan berbagai contoh para artis di Indonesia namun apakah hal tersebut dapat dijadikan tolak ukur ? Kemaslahatan bagi umat islam sendiri adalah bagaimana menjaga kepentingan-kepentingan atas keberlangsungan agama islam melalui pilar utama kehidupan yaitu rumah tangga dapat terjaga dengan baik dan dari dua pemikiran di atas dengan pertimbangan kemaslahatan dari diri sendiri dan juga anak kelak sebaiknya pernikahan beda agama di kalangan umat islam harus dilarang. Selain itu ketika melihat sisi hukum positif Indonesia keberadaan KHI pasal $40 \mathrm{C}$ memang tetap harus ada tetapi dengan berdasarkan atas kemajemukan di Indonesia maka untuk unifikasi hukum perkawinan di Indonesia di harapkan ada tujuan yang cukup fundamental dengan tentunya melihat dasar-dasar umum tujuan dan maksud dari perkawiinan yang dilihat dari setiap agama yang tentunya juga harus ada kejelasan hukum jika perkawinan beda agama di larang dengan lebih memperjelas ketentuan dari pasal 2 ayat (1) dan (2) yang menjadika tidak ada alasan lagi bahwa pernikahan selain melalui peraturan agama masingmasing dan harus di catatkan di kantor pencatat perkawinan dianggap sah walaupun dengan alasan perbedaan kewarganegaraan sekalipun asalkan tetap mengacu kepada syarat seusia dengan agama masing-masing dan di catatkan dalam lembar negara.
\end{abstract}

Kata Kunci: Perkawinan, Beda Agama, Kritikan, di Indonesia, Prespektif Islam 


\section{Pendahuluan}

Maraknya dalam beberapa waktu terakhir pasangan-pasangan artis yang menjadi figur masayrakat melaksanakan pernikahan beda agama dan hal tersebut seperti menjadi hal yang sudah biasa dimana sebagaian besar masayrakat hal tersebut adalah hak bagi setiap pasangan untuk melaksanakannya. Selain itu pernikahan yang dilakukan oleh beberapa pasangan di Indonesia pada perjalananya cukup bahagia dan terlihat sangat harmonis bahkan dapat membina keluarganya dengan baik, sebagai contoh pasangan Jamal Mirdad yang Muslim menikahi Lidya Kandau yang merupakan Nasrani dan pernikahan mereka sampai saat ini tetap berjalan baik-baik saja. Walaupun dilain pihak ada pernikahan beda agama yang tidak bertahan lama karena dianggap perbedaan prinsip yang sangat mendalam apalagi setelah pasangan tersebut memiliki anak, tentunya akan muncul kebimbangan dalam diri anaknya untuk menentukan agama yang akan dipeluk anak tersebut.

Fenomena perkawinan beda agama di beberapa kalangan di Indonesia seperti sudah menjadi hal yang biasa, ada beberapa kalangan muslim yang yang menyatakan bahwa perkawinan beda agama bagi seseorang laki-laki muslim dengan ahli kitab masih diperbolehkan dengan alasan bahwa di dalam Al Qur'an hal tersebut diperbolehkan seperti dalam surat Al'Maidah ayat 5 yang pada intinya diperbolehkan untuk mengawani para perempuan yang ahli kitab sebelum kamu. ${ }^{1}$ Namun ada beberapa ahli yang masih meragukan bukan dalam artinya meragukan ayat tersebut tetapi lebih meragukan apakah pada saat ini ahli kitab yang diidentikan oleh beberapa ahali kepada kaum Yahudi dan Nasrani masih terjaga seperti saat dulu. Memang sebaiknya pernikahan agama tidak dilakukan tetapi pada kenyataanya banyak terjadi dan bahkan tidak hanya laki-laki muslim tetapi perempuan muslimah menikahi laki-laki non muslim dan sebagian ada yang mengangap bahwa itu adalah hak asasi bagi mereka dengan mengatasnamakan kesetaraan gender ${ }^{2}$ dalam bidang perkawinan.

${ }^{1}$ Qur'an surat Al-Maidah ayat 5 berarti: "Pada hari ini dihalalkan bagimu yang baik-baik. Makanan (sembelihan) orang-orang yang diberi Al Kitab itu halal bagimu, dan makanan kamu halal (pula) bagi mereka. (Dan dihalalkan mangawini) wanita yang menjaga kehormatan diantara wanita-wanita yang beriman dan wanitawanita yang menjaga kehormatan di antara orang-orang yang diberi Al Kitab sebelum kamu, bila kamu telah membayar mas kawin mereka dengan maksud menikahinya, tidak dengan maksud berzina dan tidak (pula) menjadikannya gundik-gundik. Barangsiapa yang kafir sesudah beriman (tidak menerima hukum-hukum Islam) maka hapuslah amalannya dan ia di hari kiamat termasuk orang-orang merugi."

${ }^{2}$ Gender adalah perbedaan yang tampak pada laki-laki dan perempuan apabila dilihat dari nilai dan tingkah laku. Dalam Women's Studies Encyclopedia dijelaskan bahwa gender adalah suatu konsep kultural, berupaya 
Indonesia sebagai negara yang majemuk dalam berbagai hal termasuk diantaranya kemajemukan agamanya yang sangat beragam tentunya akan menjadi suatu hal yang menarik ketika permasalahan perkawinan beda agama ditarik kedalam hukum postif Indonesia yang memang khusus kepada permasalahan perkawinan, dimana menurut hukum positif Indonesia segala hal yang berhubungan dengan permasalahan perkawinan diatur dalam Undang-undang Nomor 1 tahun 1974, namun sayangnya perkwainan beda agama dalam undang-undang tersebut tidak mengaturnya sehingga jika dilihat sekilas ada kekosongan hukum atas peraturan tentang perkawinan beda agama. Di lain hal khusus untuk masayrakat muslim di Indonesia lebih dikhususkan penggunaan Kompilasi hukum Islam yang dibentuk berdasarkan Instruksi Presiden Nomor 1 tahun 1991 terutama di pasal 40 C KHI telah jelas bahwa laki-laki muslim dilarang untuk menikahi perempuan non muslim, hal ini juga asih menjadi perdebtan jika kita lihat karena di dalam Al Qur'an masih diperbolehkan.

Realitas yang timbul di dalam masyarakat sebenarnya harus menjadi perhatian yang serius oleh setiap pihak berkenaan dengan perkawinan beda agama, hal yang menjadi fokus dalam tulisan ini adalah kekosongan hukum positif perkawinan Indonesia yang mengatur perkawinan beda agama shingga banyak pasangan yang manfaatkan hal tersebut untuk tetap melaksanakan pernikahan beda agama di luar negeri dan baru meminta pengesahan di Indonesia, permasalahan selanjutnya adalah tentang pertentangan hak yang membolehkan dan tidak antara laki-laki dan perempuan muslim yang ingin mewujudkan rasa keadilan dalam dimensi pernikahan beda agama dalam Islam di Indonesia.

\section{Pengertian dan Dasar Hukum Perkawinan Beda Agama}

Sebelum mencari tahu pengertian perkawinan beda agama, maka lebih baik melihat dahulu pengertian dari perkawinan itu sendiri, pengertian perkawinan menurut undang-undang perkawinan adalah ikatan lahir batin antara seorang pria dan wanita sebagai suami isteri dengan tujuan untuk membentuk keluarga (rumah tangga) bahagia dan kekal berdasarkan Ketuhanan Yang Maha Esa. ${ }^{3}$ Sedangkan pengertian Perkawinan beda agama adalah ikatan lahir batin antara seorang pria dan seorang wanita yang berbeda agama, yang karena berbeda agama, menyebabkan tersangkutnya dua peraturan yang berlainan mengenai syarat-syarat dan tata cara

membuat perbedaan (distinction) dalam hal peran, perilaku, mentalitas, dan karakteristik emosional antara laki-laki dan perempuan yang berkembang dalam masyarakat. Lihat Mufidah $\mathrm{Ch}$, Paradigma Gender, Bayumedia Publishing, Malang, 2004, hlm. 4-9

${ }^{3}$ Undang-undang Perkawinan Nomor 1 Tahun 1974 Pasal 1 
pelaksanaan perkawinan sesuai dengan hukum agamanya masing-masing, dengan tujuan untuk membentuk keluarga bahagia dan kekal berdasarkan Ketuhanan Yang Maha Isa. ${ }^{4}$

Undang-undang Nomor 1 Tahun 1974 tentang Perkawinan memuat asas penting berbunyi "Perkawinan adalah sah apabila dilaksanakan menurut hukum masing-masing agamnaya dan kepercayaannya itu" (Pasal 2 ayat (1)). Pasal ini mengandung asas "Menurut Hukum Agama". Asas ini berlaku untuk seluruh perkawinan yang dilaksanakan oleh warganegara Indonesia; termasuk" perkawinan campuran”. Bagi warga negara Indonesia berlaku ketentuan tersebut.

Mengenai pengaturan hukum "Perkawinan Campuran" (khususnya perkawinan antar pemeluk agama yang berbeda) dalam Negara Republik Indonesia berdasar Pancasila ada perbedaan pendapat dikalangan para pakar hukum di Indonesia. Sekurang-kurangnya ada tiga pendapat. Pendapat Pertama menyatakan bahwa Negara Republik Indonesia berdasar Pancasila menghormati agama-agama dan mendudukkan hukum agama dalam kedudukan fundamental. Dalam negara berdasar Pancasila tidak boleh ada aturan hukum yang bertentangan dengan hukum agama. Agama-agama yang ada di Indonesia melarang perkawinan antar pemeluk agama yang berbeda. ${ }^{5}$ Pendapat ini menyatakan bahwa UU Perkawinan tidak mengatur "perkawinan (campuran) antar agama”. Tiap agama telah ada ketentuan tersendiri yang melarang perkawinan antar agama. H. M. Daut Ali menyatakan: ${ }^{6}$

(1) Sikap Negara atau penyelenggara negara dalam mewujudkan perlindungan hukum haruslah sesuai dengan cita hukum bangsa dan kaidah fundamental negara serta hukum agama yang dipeluk oleh bangsa Indonesia;

(2) Perkawinan antar orang-orang yang berbeda agama, dengan berbagai cara pengungkapannya, sesungguhnya tidaklah sah menurut agama yang diakui keberadaannya dalam Negara Republik Indonesia. Dan karena sahnya perkawinan didasarkan pada hukum agama, maka perkawinan yang tidak sah menurut hukum agama tidak sah pula menurut Undang-undang perkawinan Indonesia;

${ }^{4}$ dikutip dari Nj. Aisjah Dachlan, Membina Rumah Tangga Bahagia, hal. 96

${ }^{5}$ Pendapat ini dikemukakan oleh: H. M. Daut Ali, Muchtar Zarkasyi, Hasan Basri (ketua MUI), Bismar Siregar, H. Bustanul Arifin, H. Wasit Aulawi, dan lain-lain. Lihat Bab V tentang Pengaturan dan Pengertian perkawinan campuran.

${ }^{6}$ H.M. Baut Ali, Sikap Negara dalam Mewujudkan Perlindungan Hukum Bagi Warganegara dan Perkawinan antar Pemeluk Agama yang Berbeda, dalam "Mimbar Hukum” No 2 Tahun I halaman 1-7. 
(3) Perkawinan antar orang-orang yang berbeda agama adalah penyimpangan dari pola umum perkawinan yang benar menurut hukum agama dan Undang-undang Perkawinan yang berlaku di Indonesia.

Dasar hukum adanya perkawinan beda agama sendiri sebenarnya di dalam Al Qur'a ada dua pandangan baik yang membolehkan dan tidak membolehkan, ayat-ayat yang tidak membolehkan (mengahramkan) perkawinan beda agama, para sebagian ulama berpegang kepada ayat-ayat Al Qur'an yang dikutip seperti di bawah ini:

“Janganlah kamu menikah dengan perempuan-perempuan musyrik sebelum mereka beriman. Perempuan budakyang beriman lebih baik daripada perempuan musyrik sekalipun ia menarik hatimu. Juga janganlah menikahkan (perempuanmu) dengan laki-laki budak musyrik sebelum mereka beriman. Seorang laki-laki budak beriman lebih baik daripada seorang laki-laki musyrik sekalipun ia menarik hatimu. Mereka (kaum musyrik) akan membawa ke dalam api (nereka) ....” (QS. Al-Baqarah: 221).

Ayat berikutnya adalah:

“Hai orang-orang beriman! Jika perempuan-perempuan beriman datang berhijrah kepadamu, ujilah mereka; Allah mengetahui keimanan mereka; bila sudah kamu pastikan mereka perempuan-perempuan beriman, janganlah kembalikan mereka kepada kaum kafir; mereka (kaum mukmin wanita) tidak halal (sebagai istri) bagi mereka (kaum kafir), dan mereka (kaum kafir) pun tidak halal (sebagai suami) bagi mereka (kaum mukmin wanita). Dan berikanlah kepada mereka (kaum kafir) apa (maskawin) yang telah mereka bayar. Kemudian, tiada salah kamu menikah dengan mereka (kaum mukmin wanita), asal kamu bayar maskawin mereka. Dan janganlah kamu berpegang kepada tali perkawinan dengan perempuan-perempuan kafir; dan hendaklah kamu minta maskawin yang telah kamu bayarkan, dan biarlah mereka (orang-orang kafir) meminta apa yang telah mereka bayarkan (maskawin dari perempuan yang datang kepadamu). Itulah ketentuan Allah; Ia memberikan keputusan yang adil antara kamu. Dan Allah Maha Tahu, Maha Bijaksana” (QS. Al-Mumtahanah: 10).

Jika dilihat dari dua ayat diatas dapat disimpulkan bahwa menikahi non-Muslim baik bagi laki-laki maupun perempuan muslim hukumnya haram. Cara pandang seperti ini dikarenakan sebagian masyarakat Muslim masih beranggapan bahwa yang termasuk dalam katagori musyrik adalah non Muslim, termasuk diantaranya Kristen dan Yahudi. Namun, pertanyaan yang perlu 
dikemukakan adalah apakah non-Muslim (Kristen dan Yahudi) masuk dalam katagori musyrik? Kalau tidak, lalu apa yang dimaksud dengan “musyrik” dalam al-Qur'an?

Sebagian Ulama, diakui Imam al-Razi, berpandangan bahwa dalam beberapa ayat di dalam al-Qur'an ${ }^{7}$ menyebut Kristen dan Yahudi sebagai musyrik. Katagori musyrik dalam kedua agama samawi tersebut, dikarenakan orang-orang Yahudi menganggap Uzair sebagai anak Tuhan, sedang orang-orang Kristen menganggap al-Masih sebagai anak Tuhan.

Namun pandangan ini tidak serta merta bisa dijadikan pegangan, karena dalam ayat lain ditemukan paradigma lain tentang musyrik. Dapat dilihat bagaimana al-Qur'an secara cermat dan jelas membedakan pengertian antara kaum musyrik dan Ahli Kitab. Dalam surat Al-Baqarah ayat 105, Allah berfirman artinya:’Orang-orang kafir dari Ahli Kitab dan orang-orang musyrik tidak menginginkan diturunkannya suatu kebaikan kepadamu dari Tuhanmu...” Dalam surat AlBayyinah ayat 1, Allah juga menyebutkan "Orang-orang kafir dari Ahli Kitab dan orang-orang kafir musyrik tak akan melepaskan (kepercayaan mereka) sampai datang kepada mereka bukti yang nyata."

Karena itu perlu diidentifikasi mengenai siapa sebenarnya yang dikategorikan oleh al-Qur'an sebagai orang musyrik, yang kemudian haram dikawini oleh orang-orang Islam. Dikatakan musyrik bukan hanya mempersekutukan Allah tapi juga tidak mempercayai salah satu dari kitab-kitab samawi, baik yang telah terdapat penyimpangan ataupun yang masi asli; disamping tidak seorang nabi pun mereka percayai. Adapun Ahli Kitab adalah orang yang mempercayai salah seorang seorang nabi dari nabi-nabi dan salah satu kitab dari kitab-kitab samawi, baik sudah terjadi penyimpangan pada mereka dalam bidang kaidah atau amalan. Sedangkan yang disebut orang-orang mukmin adalah orang-orang yang percaya dengan risalah Nabi Muhammad baik mereka lahir dalam Islam ataupun kemudian memeluk Islam, yang berasal dari Ahli Kitab atau kaum musyrik, ataupun dari agama mana saja.

Kedua, bahwa tujuan dari diberlangsungkannya pernikahan adalah untuk membangun tali kasih (al-mawaddah) dan tali sayang (al-rahmah).$^{8}$ Di tengah rentannya hubungan antar agama saat ini, pernikahan beda agama justru dapat dijadikan wahana untuk membangun toleransi dan kesepahaman antara masing-masing pemeluk agama. Bermula dari ikatan tali kasih dan tali sayang, kita rajut kerukunan dan kedamaian.

\footnotetext{
${ }^{7}$ QS. At-Taubah ayat 30-31

${ }^{8}$ QS. Ar Ruum ayat 20-23
} 
Ketiga, semangat yang dibawa Islam adalah pembebasan, bukan belenggu. Dan tahapantahapan yang dilakukan oleh al-Qur'an sejak larangan pernikahan dengan orang musyrik, lalu membuka jalan bagi pernikahan dengan Ahli Kitab merupakan sebuah tahapan pembebasan secara evolutif. Dan pada saatnya, kita harus melihat agama lain bukan sebagai kelas kedua, melainkan sebagai warga negara. ${ }^{9}$

\section{Praktek Perkawinan Beda Agama di Indonesia}

Praktek perkawinan beda agama selama ini yang dilaksanakan warga negara Indonesia di luar negeri dianggap sah menurut Undang-undang Nomor 1 tahun 1974 selama perkawinan tersebut tunduk kepada hukum negara yang menjadi tempat dilangsungkannya perkawinan tersebut $^{10}$ tanpa melihat lebh jelas apakah perkawinan tersebut seagama ataupun beda agama kemudian selambat-lambatnya dalam waktu satu tahun setelah perkawinan tersebut maka harus dicatatkan di kantor pencatat perkawinan tempat pasangan tersebut tinggal untuk mendapatkan legitimasi atas perkawinan tersebut. ${ }^{11}$ Namun mengacu kepada Pasal 2 ayat (1) dan (2) dan Pasal 56 ayat (1) dan (2), secara tegas dikatakan bahwa sahnya perkawinan di Indonesia adalah berdasarkan agama, sedangkan pencatatan merupakan aspek administratif demi ketertiban sebagai warga negara dan disisi lain, perkawinan di luar negeri hanya memperhatikan aspek keperdataanya saja, maka sahnya perkawianan hanya semata-mata berdasarkan kesepakatan dan seterusnya dicatat secara administratif. ${ }^{12}$ Tanpa mengabaikan kemungkinan keabsahan pernikahan di luar negeri yang berdasarkan hukum setempat adalah juga berdasakan hukum agama setempat, tapi banyak yang melakukan perkawinan tersebut karena terganjal oleh permasalahan di Indonesia. Permasalahn yang timbul tentunya berkenaan dengan perkawinan beda agama dan yang menjadi pertanyaan apakah kepastian hukum akan di dapat ketika hanya pencatatan perkawinan secara administratif saja mengingat pengaturan tentang perkawinan yang sah menurut hukum perkawinan di Indonesia harus di dahului oleh aspek agama dalam salah satu unsur pengesahan dari perkawain tersebut baru kemudian dicatatkan. Berbicara tentang kepastian hukum yang akan diterima bagi pasangan beda agama di Indonesia, ntuk sementara di dalam

\footnotetext{
${ }^{9}$ Nurchalish Madjid, dkk, Fiqih Lintas Agama Membangun Masyarakat Inklusif-Pluralis, Paramadina, Jakarta, 2004, hal. 165.

${ }^{10}$ Undang-undang Perkawinan Nomor 1 Tahun 1974 Pasal 56 ayat (1)

${ }^{11}$ Undang-undang Perkawinan Nomor 1 Tahun 1974 Pasal 56 ayat (2)

12 Murdiarti Trisnaningsih, Relevansi Kepastian Hukum dalam Mengatur Perkawinan Beda Agama di Indonesia, CV. Utomo, Bandung, 2007, hlm. 56
} 
Undang-undang Nomor 1 tahun 1974 hanya mengatur perkawinan campur yang pengertiannya sangat berbeda dengan perkawinan beda agama karena dalam rumusannya perkawinan campuran terjadi karena adanya perbadaan status kewarganegaraan ${ }^{13}$, sedangkan untuk sahnya perkawinan tesebut tetap mengacu kepada ketentuan Pasal 2 ayat (1) dan (2) yang menyatakan harus menurut agama masing-masing.

Salah satu contoh legalisasi perkawinan beda agama pernah terjadi dalam bentuk Yurisprudensi Mahkamah Agung Register Nomor 1400K/Pdt/1986 dalam kasus perkawinan antara Andi Vonny Gani P beragama Islam dan Adrianus Petrus Hendrik Nelwan beragama Kristen Protestan yang inti dari yurisprudensi ini menyatakan bahwa perkawinan dari mereka dapat dilangsungkan di kantor catatn sipil Daerah Khusus Ibukota Jakarta dengan beberapa pertimbangan bahwa Undang-undnag Nomor 1 tahun 1974 tidak memuat suatu ketentuan apapun yang menyebautkan bahwa perbedaan agama antara calon suami istri adalah dilarang atau merupakan halangan perkawinan. Hal ini sejalan dengan Undang-Undang Dasar 1945 Pasal 27 yang menyatakan bahwa "semua warganegara bersamaan kedudukannya dalam hukum", sekalipun berbeda agama. Alasan lainnya dikatakan tidak dapat dibenarkan terus berlangsungnya kekosongan hukum terhadap kenyataan dan kebutuhan masyarakat seperti perkawinan beda agama. $^{14}$

Suatu pertanyaan besar yang akan muncul adalah pengguanan Pasal 57 dalam Undangudanag Perkawinan dapat dijadikan sebagai alasan pembenar dan sementara dianggap merupakan hal yang memberikan kepastian hukum dalam perkawinan beda agama melalui proses adopsi pertauran, tapi apakah hal tersbut membuat semakin tidak jelas dalam hal mencari kepastian hukumnya?

\section{Perspektif HAM dalam melihat Perkawinan Beda Agama}

Sebelum melihat lebih jauh bagaimana Hak Asasi Manusia (HAM) melihat permasalahn ini mari kita lihat dahulu bagaimana kajian Islam tentang HAM, alasanya karena dalam tulisan ini berusaham melihat perkawinan beda agama melalui kacamata filsafat hukum Islam sehingga ada batasan ketika menggunakan HAM adalah HAM yang berperspektif ke-Islam-an.

Pandangan Islam sendiri tentang hak asasi sebagaimana diatur di dlam syariat bahwa ada garis pemisah antara "hak Allah" dan "Hak Manusia". Hak Allah adalah kewajiban yang

\footnotetext{
${ }^{13}$ Undang-undang Perkawinan Nomor 1 Tahun 1974 Pasal 57

${ }^{14}$ Lihat Murdiarti Trisnaningsih, op.cit, hlm. 59-62
} 
dicanngakan kepada setiap manuasia untuk dilaksanakannya yang mengandung makan adanya pengakuan terhadap keesaan, kemahakuasaan dan keunikannya atau dengan kata lain hak-hak manusia dalam perspektif Islam adalah ketentuan moral yang diatur oleh hukum Allah. HAM dalam Islam adalah menempatkan manusia dalam suatu setting dimana hubungannya dengan Tuhan sama sekali tidak disebut dalam artian HAM diperoleh secara alamiah sejak kelahiran. ${ }^{15}$

Jauh sebelum munculnya Universal Declaration of Human Rights, Allah telah mendeklarasikan HAM secara universal guana menata perdaban dunia melalui perantaraan Rasul Muhammad SAW bagi setiap umat dan kesalahan pihak lain yang memandang ajaran Islam tentang HAM adalah ketidaktahuan bahwa ajaran Islam telah lengkap di dalam Al Qur'an tentang HAM yang secara kongkret dan dapat memberikan kepastian dalam pedoman hidup. Perspektif HAM di dalam Islam akan menyentuh kebebasan dengan memberikan kebebasan beragama tanpa boleh menggangu agama lain, kebebasan berpikir dan mengeluarkan pendapat, kebebasan sosial dan politik, selain itu memberikan persamaan yang berarti Islam telah membebaskan manusia dari kungkungan diskriminatif yang dibuat oleh manusia sendiri (Islam melarang kelas adanya perbudakan di muka bumi) dan Islam juga memberikan keadilan kepada setiap manusia yang semuanya itu merupakan fitrah yang diberikan oleh Allah SWT. Permasalahan HAM yang juga diangkat dalam Islam adalah penanggulangan perbedaan etnis dimana hal ini dibuat sendiri oleh manusia, untuk itu Al Qur'an memfasilitasinya dengan baik-baik, permasalahan lain juga permasalahan kesetaraan gender di dalam Islam yang juga ada hubungannya dengan kesetaraan gender dalam perkawinan.

Sedikit memberikan uraian tentang perspektif gender dalam Islam, dimana sebenarnya tidak ada secara eksplisit dimunculkan kata-kata gender di dalam Al Qur'an namun relasi yang dapat dihubungkan adalah dengan kata al rijal dan al nisa. Kata al rajul pada umumnya digunakan untuk laki-laki yang sudah dewasa. Dalam surat Al-Baqarah ayat 282 disebutkan kata rajul mempunyai kriteria tertentu, bukan hanya mengacu kepada jenis kelamin, tetapi juga kualifikasi budaya tertentu terutama sifat kejantanannya (masculinity). Kata al rijal jamak dari al rajul menggambarakan kualitas moral dan budaya seseorang, di dalam Al Qur'an kata tersebut disebutkan sebanyak 55 kali dan mempunyai berbagi makan antara lain berarti gender laki-laki tertentu dengan kapasitas tertentu pula seperti pelindung, pemimpin, orang laki-laki maupun perempuan, nabi atau rasul, tokoh masyarakat, budak atau hamba sahaya. Sedangakan kata al nisa adalah bentuk jamak dari al

${ }^{15}$ Ibid, hlm. 99-100 
mar'ah yang berarti erempuan yanf telah matang atau dewasa, dalam Al Qur'an kata al nisa terulang sebanyak 59 kali dengan makna gender adalah perempuan atau istri dan bersifat terbatas dibandingkan kata al rijal, pada umumnya digunakan nisa untuk perempuan yang sudah dewasa, berkeluarga, janda buakan perempuan dibawah umum dan lebih banyak digunakan dalam konteks tugas-tugas reproduksi perempuan. ${ }^{16}$

Kembali ke permasalahan utama dalam tulisan ini bagaimana HAM sebenarnya melihat perkawinan beda agama pertama jika dilihat secara HAM umum adalah keinginan suatu gerakan tentang perkawinan beda adalah berdasarkan atas persaaan cinta tanpa harus membawa ursuan agama karena urusan agama adalah urusan pribadi sehingga harus dipisahkan. ${ }^{17}$ Sedangkan di dalam HAM perspektif Islam sebenarnya masih ada perdebatan antara golongan para penafsir lama dan baru dalam agama Islam pada ayat Al Baqarah ayat 221 dan Al Mumtahanah ayat 10. Permasalahan yang awal dalam hal larangan mengawini perempuan musyrik, tidak ditujukan pada perempuan Ahli Kitab meskipun kafir dan berbuat syirik. Perkembangan kekekinian yang makin mengkaburkan adalah makna perempuan musyrik, sebab selain muncul interpretasi bahwa dimaksudkan sebagai perempuan musyrik adalah hanya musyrik arab dan menjadi pertanyaan besar tentang keberadaan musyrik Arab itu sendiri saat sekarang. Sehingga lrangan mengawini perempuan kafir musyrik dipertanyakan pula keberadaanya. ${ }^{18}$ Permasalahan penafsiran memang dikembalikan lagi kepada bagaimana para penafsir tersebut menafsirkan ayat-ayat Al Qur'an yang tentunya menggunakan pendekatan metode penafsiran yang harus benar pula. Bahwa memang ada pergesaran jika dilihat selama ini bahwa larangan perkawinan beda agama sudah mulai terkikis dengan banyakknya kajian-kajian dan upaya ijtihad dari beberapa kalanagn ulama sendiri, namun yang patut menjadi perhatian adalah permasalahn yang akan timbul dikemudian hari.

Permasalahan yang mungkin akan timbul dari perkawnian beda agama adalah kepastian dari agama anak akibat perkawinan tersebut dan juga permasalahan kesetaraan gender antara laki-laki dan perempuan karena selama ini ada beberapa kalangan umat muslim yang tidak melarang perkawinan beda agama yang dilakukan oleh laki-laki muslim kepada perempuan non

\footnotetext{
${ }^{16}$ Lihat Mufidah Ch, Paradigma Gender, Bayumedia Publishing, Malang, 2004, hlm. 11-13 dan lihat juga penggunaan kata al rajul dan al nisa yang berkonotasi laki-laki dan perempuan dalam relasi gender Nasarudin Umar, Argumen Kesetaraan Gender Perspektif Al Quran, Paramadina, Jakarta, 1999, hlm. 167

${ }^{17}$ Dikutip dari Harian umum Pikiran Rakyat 9 April 2005 "Perkawinan Beda Agama dalam Perspektif Islam" oleh Dr. Abdul Madjid

${ }^{18}$ Murdiarti Trisnaningsih, op.cit, hlm. 132
} 
muslim, bagaimana jika perempuan muslimah menikahi laki-laki non muslim dengan mengatasnakan ksetaraan gender? Rasionalitas yang mendukung atas diperbolehkannya dengan pendekatan dari temuan penelitian bahwa dalam hal kemampuan perempuan Islam untuk mengIslam-kan anak hasil dari perkawinan beda agama lebih besar dibandingkan kemampuan yang dapat dilakukan oleh laki-laki Islam, hasil ini didapatkan dari hasil penelitian yang dilakukan di salah satu kabupaten di Yogyakarta dan garis besar dari penelitian ini menyatakan bahwa sebenarnya Agama Islam tidak melarang dilangsungkannya perkawinan beda agama baik oleh laki-laki muslim dengan perempuan non muslim dan berlaku juga bagi perempuan Islam dengan laki-laki non muslim. ${ }^{19}$

\section{Penutup}

Sebelum mengakhiri dan mencoba mengkaji dari beberapa pemikiran yang diangkat dalam tulisan ini, penulis ingin memberikan pendapat bahwa sebenarnya untuk memberikan batasan atas larangan atau tidak terhadap perkawinan beda agama, dalam hal ini yang ingin dilihat adalah keberadaan anak dan maslahat dari perkawinan tersebut terlepas yang melangsungkan perkawinan tersebut laki-laki Islam dengan perempuan non-muslim dan sebaliknya.

Dilihat dari sisi anak pastinya akan muncul suatu kebingungan dalam menentukan aqidah anak di masa depan, hal ini mungkin terjadi ketika dia melihat perbedaan agama orang tuanya padahal ada kewajiaban bagi setiap orang tua untuk memberikan pelajaran dan pendidikan agama sedini mungkin kepada anak terutama dalam Islam sendiri dan dilain hal untuk mendapatkan pendidikan agama adalah hak anak. Hal yang paling mungkin timbul adala kebingunangan si anak dalam menentukan pilihan agamanya walaupun ada alasan setelah dewasa dia akan memilih sendiri, tapi bagaimana selama dia belum dianggap dewasa, apakah degan mencampuradukan dua agama berbeda menjadi hal yang wajar dan tidak menjadi masalah bagi setiap agama yang bersangkutan.

Di sisi lain juga ada kemaslahatan bagi setiap umat muslim sendiri dalam menjaga kemurnian dari ajaran agama Islam yang akan dijalankan dalam kehidupan pribadi dan keluarganya kelak, memang banyak bukti bahwa perkawinan beda agama langgeng dan tidak masalah dengan berbagai contoh para artis di Indonesia namun apakah hal tesebut dapat

\footnotetext{
${ }^{19}$ Ibid, hlm. 133-134
} 
dijadikan tolak ukur? Kemaslahatan bagi umat Islam sendiri adalah bagaimana menjaga kepentingankepentingan atas keberlangsungan agama Islam melalui pilar utama kehidupan yaitu rumah tangga dapat terjaga dengan baik dan dari dua pemikiran diatas dengan pertimbangan kemaslahatan bagi diri sendiri dan juga anak kelak sebaiknya pernikahan beda agama di kalangan umat muslim harus dilarang. Selain itu ketika melihat sisi hukum positif di Indonesia keberadaan KHI pasal $40 \mathrm{C}$ memang tetap harus ada tetapi dengan berdasarkan atas kemajemukan di Indonesia maka untuk unifikasi hukum perkawinan di Indonesia diharpakan ada perubahan yang cukup fundamental dengan tentunya melihat dasar-dasar umum tujuan dan maksud dari perkawinan yang dilihat dari setiap agama yang tentunya juga harus ada kejelasan hukum jika perkwinan beda agama dilaranga dengan lebih meperjelas ketentuan dari Pasal 2 ayat (1) dan (2) yang menjadikan tidak ada alasan lagi bahwa pernikahan selain melalui peraturan agama masing-masing dan harus dicatakan di kantor pencatat perkawinan dianggap sah walaupun dengan alasan perbedaan kewarganegaraan sekalipun asalakan tetap mengacu kepada syarat sesuia dengan agama masing-masing dan dicatakan dalam lembaran negara.

Melalui cara dengan menegaskan bahwa perkawinan beda agama dilarang dalam bentuk unfikasi hukum perkawinan di Indonesia tentunya tidak akan ada kekosongan hukum lagi dan selain itu juga hal ini dapat memberikan rasa keadilan dan kesetaraan gender bagi laki-laki dan perempuan karena tidak ada diskriminasi bahwa perkawinan beda agama hanya boleh dilakukan oleh laki-laki muslim saja, namun juga perlu menjadi perhatian bahwa kajian ini harus didasari pada manfaat dan kemaslahatan umat itu sendiri.

\section{Daftar Pustaka}

Al Qur'an

Mufidah Ch, 2004, Paradigma Gender, Bayumedia Publishing, Malang, Murdiarti Trisnaningsih, 2007, Relevansi Kepastian Hukum dalam Mengatur Perkawinan Beda Agama di Indonesia, CV. Utomo, Bandung,

Nasarudin Umar, 1999, Argumen Kesetaraan Gender Perspektif Al Quran, Paramadina, Jakarta

H.M. Baut Ali, Sikap Negara dalam Mewujudkan Perlindungan Hukum Bagi Warganegara dan Perkawinan antar Pemeluk Agama yang Berbeda, dalam "Mimbar Hukum” No 2 Tahun I Harian umum Pikiran Rakyat 9 April 2005 "Perkawinan Beda Agama dalam Perspektif Islam" oleh Dr. Abdul Madjid 